\title{
Japan may lift industry-academy barrier
}

[TOKYO] Japan has announced plans to set up an inter-ministerial committee to explore ways to make university researchers more free to collaborate with industry.

The committee, whose creation was announced by prime minister Keizo Obuchi last week, will decide by the autumn whether to recommend a relaxation in the current civil service law. This forbids employees of national universities from taking part in profit-making activities.

Obuchi has set up the committee in response to controversy over the appointment by the electronics company Sony of an economics professor from Hitotsubashi University, Iwao Nakatani, to its board of directors (see Nature 398, 643; 1999).

The Ministry of Education, Science, Sports and Culture (Monbusho), had intended to exempt Nakatani from a law prohibiting academics from holding external posts. But this move was rejected by the National Personnel Authority, the government's central personnel agency, leading Nakatani to resign from his university post.

The plan to revise the current civil service law is part of the government's latest jobcreation package. The $¥ 500$ billion (US\$4.2 billion) package, approved by parliament last week, aims to create 700,000 jobs by supporting fast-growing industries — such as biotechnology and information sciences and promoting the commercial application of university research.

The package includes measures to allow technology licensing organizations (TLOs) - which advise on the commercial exploitation of university research - to hold patent rights to inventions made at universities.

Under the current law, rights to patents produced from national universities belong to the national treasury, and cannot be assigned to private companies without complex legal procedures.

Both industry and universities hope that the plan will improve links between industry and academia, and encourage university researchers to set up venture businesses.

The Ministry of International Trade and Industry (MITI) runs a programme with Monbusho to set up TLOs and venture businesses at universities. It supports the involvement of university scientists in business.

"If university researchers were allowed to take up positions in private companies, this could stimulate entrepreneurial spirit within Japanese universities," says a MITI official.

Current restrictions mean that ventures set up by university researchers have to recruit staff from outside the university, or appoint postgraduate students as managers.

Examples are Tokyo University's Centre for Advanced Science and Technology Incubation (see Nature 396, 9; 1998) and Synthesis, a company set up by professors from Osaka and Kyoto universities.

"It seems silly that we have to make so many compromises and overcome numerous restrictions in order to run a business," says Kozo Murakami, professor in engineering at Osaka University and a founder member of Synthesis, which designs and develops large-scale integrated circuits.

The company is managed by postgraduate students, while the professors are only allowed to give technical guidance. "I hope we would be able to take a more active role in management if the restrictions were to be eased," he says.

Although some universities still disapprove of academic staffbecoming involved in business, the private sector has welcomed the government's move to encourage collaboration with university researchers.

"Companies would benefit a lot from gaining a voice from the academic community," says Takuji Nakamura, of the Kansai Technology Licensing Organization, which helps draw up contracts for collaborations between universities and industrial laboratories. "But we must first remove the legal barrier that restricts effective communication between the two worlds." AsakoSaegusa

\section{South African government seeks reassurances on AIDS initiative}

[CAPE TOWN] South Africa's Minister of Health, Nkosazana Zuma, has confirmed she has not rejected an offer by the US pharmaceutical company Bristol-Myers Squibb (BMS) to donate $\$ 100$ million over the next five years towards fighting AIDS in southern Africa (see Nature 399, 96; 1999).

But, speaking on South African radio, Zuma said that the offer must be modified to conform with the government's healthcare policy before it is endorsed.

The initiative, dubbed 'Secure the Future', is targeted at South Africa, Botswana, Lesotho, Namibia and Swaziland. On its announcement last month, the South African Department of Health said it wished to be "an active partner in this effort".

According to Jon Weisberg, a spokesman for BMS, one important feature of the initiative is the establishment of a 'virtual institute', funded by BMS. This will assess research proposals from southern African universities and health research bodies.

But the department also said that the government's endorsement was "conditional on the development of a mutually acceptable implementation plan for the South African component".

Zuma outlined four areas of concern at a

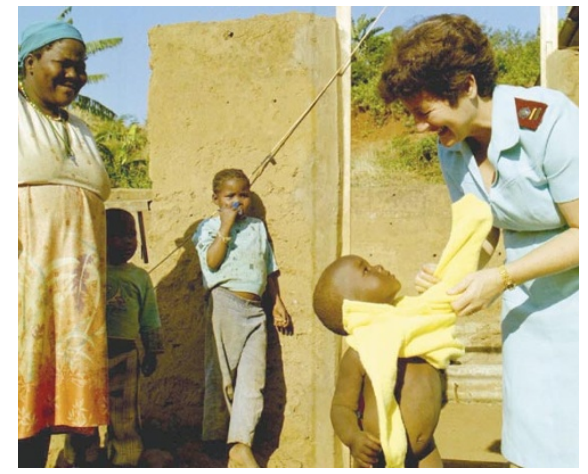

South Africa's health minister wants AIDS care to prioritize orphans - shown here in Natal.

meeting with BMS before its announcement: sending South African doctors to the United States for training in HIV treatment including clinical trials of BMS products (which Zuma rejected as irrelevant to the country's needs); financing clinical trials in South Africa; that only preclinical studies approved by the South African Medicines Research Council were acceptable; and that funding to community outreach programmes should focus on giving health care at home and caring for orphans.

Ian Roberts, special adviser to Zuma, said that Zuma told BMS that South Africa would not endorse their programme until it could view and approve the alterations to the initiative. But BMS left the plan unchanged when it was launched, and two weeks later Roberts issued a statement in which he emphasized that the government had not endorsed the initiative (see Nature 399,288 ; 1999).

But according to Mark Ahn, senior director, operations and planning (international), at BMS, Zuma had, before the meeting, appointed the heads of the Medical Research Council of South Africa and the department's HIV/AIDS/STD Directorate to the advisory board that will select the research projects to be funded.

Such studies are to be proposed by African medical institutions, and not the company. The board will also select the fellows who will participate in the health education exchange programmes.

"We are still awaiting a response from BMS on whether they are prepared to tailor their proposals to South Africa's needs," says Vincent Hlongwane, Zuma's spokesman. It is hoped that the position is clarified soon, as the first board meeting of the initiative is scheduled for 24 June.

Michael Cherry 